\title{
Theorizing Feminist Discourse / Translation
}

\author{
Barbara Godard
}

Ce texte élabore une théorie du discours féministe comme une pratique emancipatoire, un discours politique orienté autour de la construction de nouveaux savoirs et des sujets en procès. Ce discours avance une théorie du texte comme transformation critique: le discours féministe travaille le discours dominant dans un mouvement complex et ambigu entre discours. Ce je( $u)$ d'entre est figuré dans le discours féministe par le topoi de la traduction (traduction intralinguale ou intersémiotique, selon Jakobson) en tant que transcodage et transformation. C'est une traduction en deux sens: en tant que la notation du gesturale et de la parole des femmes inédits et en tant que répétition et dé/placement du discours dominant parl'effet del'étranger. Des exemples dece discours sont tirés des oeurres de Nicole Brossard, Madeleine Gagnon, Suzanne Lamy, Luce Irigaray, Hélène Cixous, etc.

La théorie dominante de la traduction comme équivalence entre deux textes est fondée sur une poétique de la transparence du langage. Ici, au contraire, l'auteure avance une théorie de la traduction comme trans(dance)form, comme transformation et performance. C'est le mîme, la répétition qui se dédouble et déséquilibre. L'équivalence se trouve dans les opérations, ceux du codage et de décodage, entre deux systèmes de textes. Comme l'auteure, la traductrice produit du sens, un sens qui vient de la manipulation du texte. Ainsi, le rôle de la traductrice dans la transformation du texte est mise en valeur, sa signature mise en évidence, ces éléments auto-réflexives mettant en évidence le travail, la textualité, le différe(a)nce de la traduction. Des modèles théoriques pour cette théorie de la traduction se trouvent du côté des théories de la citation (Antoine Compagnon) et de la parodie (Linda Hutcheon), des théories de la littérature au deuxième degré. La traduction féministe est un mode privilegé de réécriture. 
The only complete reading is the one which transforms the book into a simultaneous network of reciprocal relationships.'

- Derrida $^{1}$

Questions ${ }^{2}$ of language and gender, women's troubling relationship with language, have emerged as a central preoccupation of feminist theory and in the translation of women writers. In an increasing number, translations of texts by French feminist theorists with their playful disruptions of the dominant discourse have posed great challenges to the translator. To raise the issue of their translation in the framework of language, gender and ideology is to ask about the relationship between the theories of discourse advanced in these texts and the theories of translation which have produced the English version. Are the texts grounded in theories of equivalency (sameness), or does the meaning of the translation come from its redistributive function, as transformation? Do the translations seek to hide the work of translation and appear as naturalized in the English language, or do they function as texts, as writing, and foreground their work upon meaning?

Both theoreticians of women's discourse and of feminist translation ground their reflection in issues of identity and difference, otherness being framed linguistically in terms of gender as well as of nationality. Madeleine Gagnon develops parallels between the colonized position of Quebec and the linguistic alienation of women. Positing the existence of two language worlds, those of men and women, she advocates women use the language of the dominant to persuade and to transform it. Masquerade: 'M'approprier cette langue qui pourtant est mienne mais étrange. La disposer à ma guise et je ne traduis pas. ${ }^{3}$

Mais nous, nous avons la parole, nous avons multiplicités de paroles; celle des discours mâles qui peuvent encore servir: prenons-là (sic), nettoyons-la de toutes ses aliénations; reconnaissons ses marques phalliques et ajoutons le double du sexe qui manque; faisons notre marque; puis, nous avons la nôtre, notre parole, à inventer, à mesure que l'éveil de notre sexe se poursuit: car s'il fut refoulé par les mâles, il fut par nous, d'une certaine façon, camouflé (p. 82).

This doubled language, male discourse re-marked by the multiplicity 
of women's speech, will transform scientific discourse and its poetics of transparence. As an emancipatory practice, feminist discourse is a political discourse directed towards the construction of new meanings and is focused on subjects becoming in / by language. ${ }^{4}$ It seeks to expose ideological modes of perception throughan expansion of messages in which individual and collective experience originate from a critical stance against the social contexts of patriarchy and its language. In this, feminist texts generate a theory of the text as critical transformation.

The possibility of future feminist intervention requires an ironic manipulation of the semiotics of performance and production. From Suzanne Lamy, we learn about the way feminist discourse works upon the dominant discourse in a complex and ambiguous movement between discourses. Women's discourse is double; ${ }^{5}$ it is the echo of the self and the other, a movement into alterity. 'Cette parole toute de souplesse et de mouvements secrets vire en un discours en écho de soi-même et de $\mathrm{l}^{\prime}$ autre. ${ }^{6}$ Mobility is evident in the way women's discourse circulates from speech to writing, operating in between, intervening. 'Comment cerner cet entre qui disjoint parole et écriture? Comme mode d'intervention, la parole des femmes garde intact ses devoirs: les tâches à accomplir sont immenses' (p. 54). Speech, as gossip, as private communication among women, is nonsense (p. 33): it works upon language anarchically, shattering everything ('Activité anarchique, le bavardage que j'aime - celui qui me travaille - fait voler en éclats tout ce qui tente de se coller à lui'). But from this rupture may come meaning on a new order, not that of 'cohérence et d'unification' but of 'mouvance et pluralité' (p.21). In the to and fro movement, writing is rupture and plurality. Anchored in the collectivity of women, with an implicit feminist agenda, and characterized by a theoretical discourse which problematizes language, women's writing gives rise to:

des textes qui rendent compte d'une différenciation qui peut se manifester de façon polymorphe, sous les aspects de l'éclatement, de la pluralité, de la rupture, del'absence destructure close (p. 64).

This polymorphic quality makes of feminist discourse an 'écriture à $\operatorname{deux}^{\prime}$ (p. 39), 'un dialogue au sens plein du terme' (p. 45). Dialogic, 
the-one-within-the-other in the Bakhtinian sense of the polyphonic text, feminist discourse works to subvert the monologism of the dominant discourse.

Translation, in its figurative meanings of transcoding and transformation, is a topos in feminist discourse used by women writers to evoke the difficulty of breaking out of silence in order to communicate new insights into women's experiences and their relation to language. Confronted with a plurality of discourses, the mixture of levels of language within one national culture or heteroglossia, wherein their language is marginal with respect to the dominant discourse, women writers figure this metaphorically in terms of polyglossia or the copresence of several 'foreign' languages. Where the political and social dimensions of the languages are prominent, as in the case of feminism, the confrontational encounter of languages becomes explicit. Women writers experience the conflict of heteroglossia in a specific way as a deterrent to participation in a national tradition. The traces of this conflict have been defined as a translation effect, or ' 1 'épreuve de l'étranger.' To Antoine Berman, the dis / placement in language effected by a foreigner such as Conrad or Beckett writing in a second language is like that of the litera ry work in a foreign language translated into English or French, producing an estrangement effect or defamiliarization, the work of translation. ${ }^{7}$ Although framed as a transfer from one language to another, feminist discourse involves the transfer of a cultural reality into a new context as an operation in which literary traditions are variously challenged in the encounter of differing modes of textualization.

Everywhere women are writing their way into subjective agency, $\mathrm{dis} /$ placing themselves. There is a widespread feeling that it has been necessary to invent a new language to discuss what has been taboo. 'Inédit,' unwritten, is a recurrent term in Nicole Brossard's writing to describe herwork expressing such 'unknown' experiences of women, unknown, that is, within the dominant discourse which has positioned women as non-sense. The complex process of inscribing this unrecorded emotion is conveyed in her poem sequence, $L^{\prime}$ Aviva in terms of a double movement of translation where the emotion is first voiced and heard, then 'translated' and acted upon in sextual pleasure. ${ }^{8}$ In a second moment, this emotion of ' 1 'aviva' is translated phonetically: ' $l$ 'en suite traduite. ${ }^{\prime 9}$ The epigraph to this sequence of poems announces that ' 1 'émotion est un signe / une réplique attentive 
au sens.' The poems unfold in tandem: emotion is located and voiced, then translated by the poet into text through a process of sound association and play on words which effect a transformation in the material signifier like the reverberations and mimicry of the echo. ('La peau de décrire un instant' becomes '1'eau qui décrit car c'est lent.')

The dialogic moment of translation is at the centre of Le désert mauve, a fiction in which Brossard is translating herself, underlining the double activity of women's writing as reading/writing, as the re / reading of the already-written followed by the divining / writing of the unrecorded. ${ }^{10}$ The poetics of transparence and ethics of wholeness of writing oneself into existence through writing directly one's own experience is called into question through an examination and displacement of their reading effects. In its place is a poetics of identity that engages with the 'other woman.' 'Transformance,' it might well be called, to emphasize the work of translation, the focus on the process of constructing meaning in the activity of transformation, a mode of performance. This is to evoke the sound poem Trance(dance)form performed by Penny Kemp. ${ }^{11}$ To adopt this term is to underline the interweaving of feminist writing and feminist translation for 'Transformance' is also the collective title for the re / writing (translation) project in which Nicole Brossard has been involved with Daphne Marlatt. ${ }^{12}$ Brossard's activities of transformance stand as a model for feminist discourse/translation in its actions of re/reading and re/writing, its dialogism.

Feminist discourse is translation in two ways: as notation of 'gestural' and other codes from what has been hitherto 'unheard of,' a muted discourse, ${ }^{13}$ and as repetition and consequent displacement of the dominant discourse. Both set out to 'destroy the discursive mechanism' by assuming the feminine role deliberately, in an act of 'mimicry,' which is to convert a form of subordination into an affirmation and to challenge an order resting on sexual indifference. The effects of this 'playful repetition' make visible what has been concealed, that is the operation of the feminine in language and the fact that women are good 'mimics' because they are never reabsorbed in this function ( $\mathrm{p}$. 76). In this logic of 'supplementarity,' 'an other writing necessarily entails an other economy of meaning' (p.131). Feminist discourse works upon language, upon the dominant discourse, in a radical interrogation of meaning. '[The language work's] function would thus be to cast phallogocentrism loose from its moorings in order to 
return the masculine to its own language, leaving open the possibility of a different language. Which means that the masculine would no longer be "everything"' (p. 80).

Translation, in this theory of feminist discourse, is production, not reproduction, the mimesis which is 'in the realm of music' (p. 131) and which, by an 'effect of playful repetition' - 'women also remain elsewhere' (p.76) - makes visible the place of women's exploitation by discourse. Pretensions to the production of a singular truth and meaning are suspended. This theory focuses on feminist discourse in its transtextual or hypertextual relations, as palimpsest working on problematic notions of identity, dependency and equivalence. ${ }^{14}$ It is mimicry, repetition which redoubles as it crosses back and forth through the mirror, a logic of disruptive excess in which nothing is ever posited that is not also reversed. Linear meaning is nolonger possible in a situation caught up in the supplementarity of this reversal (p. 80). In this, feminist discourse presents transformation as performance as a model for translation. Transformation of the text is conceived within the axioms of topology. However, this is at odds with the long dominant theory of translation as equivalence grounded in a poetics of transparence.

Translation theory and practice have varied over the centuries. Each age has its own theory. Currently dominant is a theory of translation as equivalence which is grounded in a poetics of transparency. It maintains that a message may be transposed from one language to another so that the meaning of the message is preserved and there is an identity of content in the two texts: 'La traduction consiste à produire dans la langue d'arrivée l'équivalent naturel le plus proche du message de la langue du départ, d'abord quant à la signification, puis quant au style. ${ }^{15}$ There is perceived to be no opposition between signifier and signified, but an isomorphism, a complete parallelism of the content and expression, of meaning and sound (p. 97). Such a translation is characterized by the way in which certain cultural traces and also certain self-reflexive elements are eliminated from the text so that the translated text is deprived of its foundation in events. The elimination of self-reflexive elements results in the supression of signs of the author-function but also in those of the translator-function since her manipulative work on these elements is rendered invisible in the resulting conflation of the two texts. In this way are effaced the translator's dual activities of reading and (re)writing. The translator is 
understood to be a servant, an invisible hand mechanically turning the words of one language into another. The translation is considered to be a copy and not a creative utterance. In the twentieth century, this theory of translation has served to encourage experiments in machine translation.

What such a theory of translation based on equivalency ignores is the extreme difficulty in translating meaning because of the importance of co-textual (formal) and contextual relationships. ${ }^{16}$ Recent theories of translation address these relationships and move in a new direction to emphasize the work of the translator as decoder and reencoder. Translation is not merely a transcoding operation: the English 'yes' is not the same as the French 'oui' because there is also the French 'si.' Translators each have their favourite list of context-bound objects used to illustrate the fact that language is not transparent. Each language classifies and organizes the world and the translator creatively intervenes in such instances.

Contemporary theories of translation stress that equivalence in translation should not be approached as a search for sameness. It is perceived as a dialectic between signs and structures within and surrounding source language and target language texts. ${ }^{17}$ Equivalence is located between the coding / decoding operations of two text systems rather than between the contents or words of two messages. As Bassnett-McGuire frames this: Author-Text-Receiver = TranslatorText-Receiver (p. 38). Like the author, the translator is the producer of an utterance. Bassnett-McGuire also invites us to consider the relationships between the two communicative systems in terms of intertextuality (p. 79).

While intertextuality is a new concept in translation theory, such theories of the text as productivity and permutation (as intertextuality) have gained currency in semiotic approaches to literary theory, where a shift in focus from author to text and then to reader and the act of enunciation has already occurred. In translation theory, pragmatics understands the translator to be an active reader first before becoming a writer: $s$ / he is both receiver and sender of the utterance, the end and the beginning of two separate but linked chains of communication. The result, according to Octavio Paz, is 'translations of translations of translations ... Every text is uniqueand at the same time it is the translation of another text ... Every translation, up to a certain point, is an invention and as such it constitutes a unique text' 
(Bassnett-McGuire, p. 38). "The translation of a text structured like a text, functioning like a text, it is writing of a reading / writing, the historical adventure of a subject. It is not transparent with respect to the original' but as 'transformation' works upon the original to decentre it. ${ }^{18}$ Here, translation theory rejoins feminist textual theory in emphasizing the polyphony of the translated text in that it foregrounds the self-reflexive elements of the translator's / rewriter's discourse and flaunts its work, its textuality.

Translation is one among many ways of rewriting within literary systems pushing them in a certain direction through canonizations. ${ }^{19}$ New theoretical models derived from other systems of rewriting are needed to describe more precisely this paradigm of translation as a manipulation of texts whose meaning is derived from their transformation. Both quotation and pa rody concern themselves with interdiscursive repetition, repetition considered to be a thing in itself, a fact of language. Both address themselves to the ambiguities of repetition, to the fact that nothing is more refutable than the equivalence of two propositions. On the one hand, is the observation that things are repeated; on the other, the realization that repetition is a fact of language from which meaning is produced, as in the case of the refrain or rhyme. The semantic confusions which disturb the order of words in quotation between mention and use, between meaning and denotation, involve a distinction between two levels of language, a language-object and a metalanguage. The effect of this disturbance of the levels of language is to substitute for the meaning of the word, the meaning of the repetition of the word. ${ }^{20}$ The value of repetition is a supplement of meaning. The repetition of the words of others, quotation, can only be the simulacra-phantasm in the Platonic system of mimesis, the impure form and not the icone-copy, or the pure form, a resemblance and not the truth (p. 125). As such it is para-doxal, both like and unlike the doxa.

Parody too is both like and unlike, a singalong and a countersong, a re- or trans-contextualizing of previous works of art. ${ }^{21}$ Like quotation and other modes of repetition, parody is a 'mise en abyme,' a 'mirroring' of the origins of the process of realistic figuration, and consequently has a meta-fictional function. ${ }^{22}$ Like translation, parody consists of two text-worlds, those of parodist and target, received by the reader at another time and place and based on two connected models of communication. The source work is decoded by the parodist as 
reader and then encoded again in a changed form for another decoder, the reader, who will have previously read and decoded the source work. ${ }^{23}$ Parody depends on the reader's 'sideward glance' ${ }^{24}$ of recognition to activate the supplement. This lays bare the fictiveness of fiction and foregrounds its devices, so enabling them to be refunctioned for new purposes. There is an emphasis on transformation, on the role of the artist / translator as active reader and writer, and hence on the complex act of enunciation within this communication system. Even though its hypertext may be illusory, invisible behind the reproduction, translation may be categorized as 'forgerie,' and defined as 'imitation sur le régime sérieux.' ${ }^{25}$ As neutral ethos, ${ }^{26}$ parody becomes a definition for all mimesis, that is for any form of redoubling. In light of this re-writing, the concept of translation is enlarged to include imitation, adaptation, quotation, pastiche, parody-all different modes of re-writing: in short, all forms of interpenetration of works and discourses.

When translation is concerned not only with the relationship between two languages but between two text systems, literary translation becomes a text in its own right so that the traditional boundary set up to separate original works from their translations collapses. ' $\mathrm{La}$ distinction traditionelle entre texte et traduction,' writes Meschonnic, 'apparaît comme une catégorie idéaliste. Elle est ici annulée' (p. 365). As a corollary, there is a reassessment of the status of the source text overvalued in theories of translation which a re blind to the ideological implications of their textual manipulations. ${ }^{27}$

Though traditionally a negative topos in translation, 'difference,' becomes a positive one in feminist translation. Like parody, feminist translation is a signifying of difference despite similarity. As feminist theory has been concerned to show, difference is a key factor in cognitive processes and in critical praxis. Meaning decerned and assigned by the translator becomes visible in the gap or the surplus which separates target from source text. ${ }^{28}$ The feminist translator, affirming her critical difference, her delight in interminable re-reading and rewriting, flaunts the signs of her manipulation of the text. Womanhandling the text in translation would involve the replacement of the modest, self-effacing translator. Taking her place would be an active participant in the creation of meaning, who advances a conditional analysis. Hers is a continuing provisionality, awa re of process, giving selfreflexive attention to practices. The feminist translator immodestly flaunts her signature in italics, in footnotes - even in a preface. 


\section{Notes}

1. Jacques Derrida, Writing and Difference, Trans. Alan Bass (Chicago: University of Chicago Press, (1967), 1978), 24.

2. Many thanks to Sherry Simon, Lorraine Gauthier, Elizabeth Lamèche for their dialogue.

3. Madeleine Gagnon, 'Mon corps est mots,' in Hélène Cixous, Madeleine Gagnon et Annie Leclerc, La venue à l'écriture (Paris: 10 / 18, 1977), p. 69.

4. Jean Bethke Ehlstain, 'Feminist Discourse and Its Discontents: Language, Power, and Meaning.' Signs, 7, No.3 (1982), p. 617.

5. Sandra Harding in a lecture at OISE in February 1983 commented on the feature of feminist discourse, like the discourse of any marginalized group, being characterized by its double or plural perspectives on events, the view from below which was lateral as well as hierarchical, in opposition to the dominant discourse which knew only its own meanings.

6. Suzanne Lamy, d'elles (Montreal: I'hexagone, 1979), p. 46. Subsequent references are included in the text.

7. Antoine Berman, L'épreuve de l'étranger (Paris: Gallimard, 1984), 18n.

8. 'et partir de l'émotion, nuque et ça une situation du genre, énoncée dans la clarté, les plis, les intuitions et s'appliquer pour en être au bord et recommencer éprouvée toute d'éveil d'être en ses cheveux ouïe,'

- Nicole Brossard, L'Aviva (Montreal: nbj, 1985), pp. 22-23.

9. 'et l'émotion traduire nuque et là une dévotion, entendre toute allongée dans la clarté tu ris de la façon car connaître et rèver au gré très tard c'est entamer l'éternité $d$ 'être en ses cheveux $j$ / ouie

10. This self-translation is the repetition of a process as distinguished from translation of another's work which is reproduction of a product. Brian Fitch, The Status of Self-Translation,' Texte, 4 (1985), p. 117.

11. Penny Kemp, Trance(dance)form (Victoria: Soft Press, n.d.).

12. Daphne Marlatt and Nicole Brossard, Mauve (Vancouver / Montréal: Writing / nbj, 1985) and Character / Jeu de lettres (Vancouver and Montréal: Writing / nbj, 1986).

13. Luce Irigaray, This Sex Which is Not One, Trans. Catherine Porter (Ithaca: Cornell University Press, 1985), pp. 134, 132.

14. As Hélène Cixous sums it up, this double-voiced discourse is dis / placement and re / placement, dynamic inter-vention: To admit that writing is precisely working (in) the in-between, inspecting the process of the same and of the other without which nothing can live, undoing the work 


\section{2 . Tessera}

of death - to admit this is first to want the two, as well as both, the ensemble of the one and the other, not fixed in sequences of struggle and expulsion or some other form of death, but infinitely dynamized by an incessant process of exchange from one subject into the other. A process of different subjects knowing one another and beginning one another anew only from the living boundaries of the other: a multiple and inexhaustible course with millions of encounters and transformations of the same into the other and into the inbetween, from which woman takes her forms (and man, in his turn; but that's his other history).' Hélène Cixous, 'The Laugh of the Medusa,' trans. Keith and Paula Cohen, in New French Feminisms, eds. Elaine Marks and Isabelle de Courtivron (Amherst: University of Massachusetts Press, 1980), p. 254.

15. Georges Mounin, Les problèmes théoriques de la traduction (Paris: Gallimard, 1963), p.xii (my emphasis).

16. J.C. Catford, A Linguistic Theory of Translation: An Essay in Applied Linguistics (London: Oxford University Press, 1965), p. 36.

17. Susan Bassnett-McGuire, Translation Studies (London: Methuen, 1980), p. 29.

18. Henri Meschonnic, 'Poétique de la traduction,' Pour la poétique II (Paris: Gallimard, 1973), p. 307, my translation.

19. Literary criticism as interpretation, historiography, the prefatory introduction or the book review are other modes of rewriting which shape the evolution of a given literature. Such rewritings operate within constraints, those of patronage, poetics, the universe of discourse and the natural language in which they are written and, in the case of translation, especially, the original work itself (André Lefevere, Why Waste our Time on Rewrites? The trouble with interpretation and the Role of Rewriting in an Alternative Paradigm,' in The Manipulation of Literature: Studies in Literary Translation. Theo Hermans, ed. (London: Croom Helm, 1985), p. 235).

Translation (and literary) theory would try to explain how these constraints operate and how the interaction of writing and rewriting shapes a given literature.

20. Antoine Compagnon, La seconde main: ou le travail de la citation (Paris: Seuil, 1979), p. 86.

21. Linda Hutcheon, $A$ Theory of Parody: The Teachings of Twentieth Century Art Forms (London and New York: Methuen, 1985), p. 11.

22. René Payant, 'Bricolage pictural: 1'art à propos de l'art; I-Question de la Citation, II-Citation et intertextualité.' Parachute 16, 18 (1979,1980, pp. 5-8, 2532), p. 29.

23. Margaret Rose, Parody / Metafiction (London: Croom Helm, 1979), p. 26.

24. M.M. Bakhtin, Problems of Dostoevsky's Poetics, trans. Caryl Emerson, Intro. Wayne Booth (Minneapolis: University of Minnesota Press, 1984), p. 199.

25. Gerard Genette, Palimpsestes (Paris: Seuil,1982), p. 37. 
26. Linda Hutcheon, 'Ironie, satire, parodie,' Poétique, No. 46 (1981), p. 149.

27. 'La notion de transparence - avec son corollaire moralisé, la "modestie' du traducteur qui s'efface" - appartient à l'opinion, comme ignorance théorique et méconnaissance propre à l'idéologie qui ne se connaît pas ellemême. On lui oppose la traduction comme ré-énonciation spécifique d'un sujet historique, interaction de deux poétiques, décentrement, le dedansdehors d'une langue et des textualisations dans cette langue' (pp. 307-308).

28. Annie Brisset, Transformation para-doxale,' Texte,4 (1985), p. 207. 